\title{
Banking in the information society: a Brazilian vision
}

\section{Claudia Lima Marques ${ }^{1}$}

\section{INTRODUCTION}

In the last ten yeats, the financial services market in Brazil has changed dramatically. ${ }^{2}$ There has been a substantial growth in credit card, electronic banking card, telephone and Internet home banking schemes. Also, the Brazilian government has deregulated the financial market, leading to an increase in the competition of financial institutions, and, consumer protection has finally been regulated by contracts (including financial products and services). In the $1990 \mathrm{~s}$ the globalization, the openness of MERCOSUR countries and the advances in electronic communication produced large changes in the Brazilian financial and consumer credit market. All this created an interesting diversity and openness to large (and foreign) banking corporations, but also a very hard situation for low income

\footnotetext{
1 The author would like to thank Prof. Antonio Herman Benjamin (Univ. of Texas, Austin), Diplomat Ralf Holzen and Lawyer Fábio Costa Morosini for materials and comments. The author claims responsibility for all errors.

${ }^{2}$ Cf. Cláudia Lima Marques, Les contrats de crédit dans la législation brésilienne de protection du consommateur', in Iain Ransay (ed.), Consumer Law in the Global Economy (Ashgate-Dartmouth, Aldershot, England, 1997), pp. $321-348$.
} 
consumers and to the less educated people, who are easily excluded from this new 'electronic banking age'. 3

In the 1990s many national public banks in Brazil became privatized and almost all national and international banks turned from traditional commercial banks to multifunctional institutions (so-called bancos múltiplos) and today offer an increasing and very wide range of services to consumers. ${ }^{4}$ The range of services offered by banks in Brazil includes: (1). Deposit and savings (current/check accounts, automated teller macbines (ATMs), deposit/savings accounts, including investment and high interest deposit accounts, special types of savings accounts, e.g. mortgage deposit, holiday savings budget, credit account); (2). Money transmission (check, credit transfer, standing orders, direct debits, bank drafts); (3). Lending (overdrafts advances on current account, personal loans, house purchase schemes, bridging loans, credit cards); (4). Travel and foreign (foreign currency, traveler's checks, international check cashing arrangements, international money transfer); (5). Investment and taxation (safe deposit, insurance, life assurance, pension plans, tax planning, investment); and (6). Specialized advice, information and services (in general, and often tailored to suit the needs of specific market segments, such as pensioners, students, diplomats etc.). ${ }^{5}$ The Central Bank Resolution number 1524, issued on 22 September 1998, allowed the multifunctional bank to operate. The traditional commercial and investment banks turned into multifunctional banks with more and more relationships with consumers and other vulnerable actors.

Such developments in the Brazilian market occured to a greater or lesser extent in all economies in the 1990 s and they have exposed the fragiliry of the legislative consumer protection framework. The Brazilian Consumer Protection Act (Lei n. 8.078/90), the so-called Consumer Code (CDC), is a new statute. Some key effects of the Consumer Code are as follow. In the first place, it ensures against the inclusion of unfair clauses (cláusulas abusivas) in consumer contracts. Secondly, it has an influence on the general theory of contract, especially service contracts. Thirdly, it provides formal recognition of the need to provide consumers with special protection, with special rules of interpretation

\footnotetext{
"About this new 'era of change', with cross-border mergers of banks and the dominant role of financial markets at the close of the twentieth century, see lain Ramsay and Toni Williams, 'Racial and Gender Equality in Markets for Financial Services' in Peter Cartwright (ed.), Consumer Protection in Financial Services (Kluwer Law lnternational, London, 1999), p. 267.

${ }^{4}$ Since the $1990 \mathrm{~s}$, almost half of the 25 biggest Brazilian. financial institutions have changed their shareholders' control, with special emphasis in international acquisitions of national entities, see 'Gazeta Mercantil' (23 - 27 December 98) Caderno Finanças E Mercados, p. B-1.

${ }^{5}$ Adapted from Sothi Rachagan, 'Procedures for the resolution of consumer gxievances with banking services' (1998) Revista da AJURIS.Ediçä́o Especial, tomo I, (Porto Alegre, 1998), p. 202.
} 
and controlling standard contracts. ${ }^{6}$ But in financial services the Brazilian Consumet Code is based on the way consumer-bank relationships or financial products were shaped in the late 1980 s, without taking account of the advances in electronic communication and technological innovations. Nevertheless, in the Brazilian matket consumers face various problems in the area of financial setvices, such as access to the financial service, and the complexity of both purchase contracts and financial services (e.g. the recent problems with the automobile leasing), ${ }^{7}$ the lack of transparency and information, variability of costs in long-term contracts, unfair contract terms, unintelligible conditions, privacy protection, over-indebtedness, security in electronic payments and transfers, authentication of consent in electronic payments. Legal responses to these problems of the consumet are not easy to formulate.

This essay will consider only some impacts of technological innovations in financial services in Brazil (Section 2) and some aspects of transparency and fairness in the contractual relationship between banks and consumets in an emetgent country like Brazil (Section 3).

\section{TECHNOLOGICAL INNOVATIONS IN BANKING SERVICES AND CONSUMER PROTECTION IN BRAZIL}

\subsection{The Consumet of the Banking Services}

Before engaging into the analysis of the impacts of technological innovations in banking services, it would however be helpful to start with some temarks on more pragmatic elements of the Brazilian financial market. For historical reasons, the financial sector, and especially the banking one, has been very protected and less controlled by the Brazilian government. This sector has been immune to all antitrust regulations, so the concentration in this sector was and is great in Brazil; the Brazilian Banks Federation (FEBRABAN) has also developed a very special lobbying force and has successfully gained special tteatment for banking and financial services on many occasions. They also ttied to exclude the financial services to fall upon the Brazilian Consumer Code provisions.

\footnotetext{
"arques, Les contrats, pp. $322-324$.

${ }^{\prime} \mathrm{Cf}$. my communication, 'Consumer car leasing contracts - Repayment indexed in dollars - Currency devaluation - Court applies principles of Consumer code' (1999) Consumer Law Journal 7, pp. 108 $-109$.
} 


\subsubsection{Banking Services: Falling upon the Consumer Code Provisions}

The Brazilian Banks Federation (FEBRABAN) has developed a special lobbying force to exclude financial services from falling upon the Brazilian Consumer Code provisions. ${ }^{8}$ The consumer movement has answered ${ }^{9}$ and the courts have decided that the banking service shall fall upon the consumer code provisions without special treatment. ${ }^{10}$

In the past, banking relationships were limited to merchants. Today, with the multifunctional banks, a variety of operations can be contracted typically witl consumers. "The judicial teasoning ${ }^{12}$ is that banks, ex vi Article 119 of the Brazilian Commercial Code, are commercial enterprises (Article $3^{\circ} \mathrm{CDC}$ ), ${ }^{13}$ and that lending money can be considered a consumer good or product (Article $3 \rrbracket 1^{\circ} \mathrm{CDC}$ ), ${ }^{14}$ but the typical hanking activities are services (Article $3^{\circ} \ 2^{\circ} \mathrm{CDC}$ )..$^{15}$ These typical banking

${ }^{B}$ See Amold Wald, 'O direito do consumidor e suas repercussões em relação às instituiçōes frnanceiras' (jul/set 1991) Revista de Informaçäo Legislativa, (Brazil, a. 28, n. 11), p. 296; Humberto Theodoro, 'Parecer' in Revista dos Tribunais - RT 747, pp. 111 - 134; Luiz Gastão Paes de Barros Leães, forthcoming. "Nelson Junior Nexy, "Código Brasileiro de Defesa do Consumidor- Comentado pelos autores do Anteprojeto' in Ada Pellegrini Grinover et al. (eds), (Forense Universitária, Rio de Janeiro, 1998), p. 344; Newton De Lucca, 'A aplicação do Código de Defesa do Consumidor à atividade bancária' (1998) Revista Direito do Consumidor, vol. 27, PP. 78 - 87; Antonio Janyr Dall'Agnol, 'Direito do consumidor $\mathrm{C}$ serviços bancátios e linanceiros- Aplicação do CDC nas atividades bancárias' (1998) Revista Direito do Consumidor, vol. 27, pp. 7 - 17; also Cláudia Lima Marques, 'Contratos no Código de Defesa do Consunidor' 3. Ed., Ed. Revista dos Tribunais, (São Paulo, 1999), p.197 and Cláudia Lima Marques, 'Contratos bancários em tempos pós-modernos' (1998) Revista Direito do Consumidor, vol, 25, p. 19.

${ }^{30}$ Leading case: 'Código de defesa do consumidor. Bancos. Cláusula penal $10 \%$. 1. Os bancos, como prestadores de serviços especialmente contemplados no Article $3 \$ 2^{\circ}$, estão submetidos às disposições do Código de Defesa do Consumidor. A circunstância de o usuário dispor do bem recebido através da operação bancária, transferindo a terceitos, em pagamento de outros bens ou serviços, näo o descaracteriza como consunidor final dos serviços prestados pelo banco' (Resp. 57.974-RS, Min. Rliy Rosado de Aguiar, j. 29 May 1995, Superior Tribunal de Justiça, Brazil).

"Cr. Roberto Senise Lisboa, 'A relação de consumo e seu alcance no direito brasileiro' in Oliveira Mendes (ed.) Coleção Saber Juridico (São Paulo, 1997), p. 33.

12 The judicial analysis will focus on the state of Rio Gtande do Sul, where the author comes from, where the Tribunal de Justiça (hereafter TJ/RS) is one of the most progressive in Brazil. C.. APC 195.037 .338 (1996) Revista Direito do Consumidor 20 p. 182.

${ }^{13 .}$ Leading cases of the TJ/RS, in Marques, Contratos, n. 9 above, p. 199, and " 1 " Tribunal de Alçada São Paulo' (1996) Revista Direito do Consumidor 19, p. 264. This is also true in Canada, see Nicole L'Hexeux, Droit de la Consommation (4a ed., Blais, Cowansville, Québec, 1993), pp. 30 - 31.

14 Cf. 'Class Action of Ministério Público Rio Grande do Sul' (1998) Revista Direito do Consumidor 28, $\mathrm{p}$. 228. Cf. Nelson Abrão, Curso de Direito Bancário, Ed. R'T', (São Paulo, 1988), p. 69.

1s Article $3, \$ 2^{\circ} \mathrm{CDC}$ declares 'service is any activity provided in the consumption market, in exchange for remuneration, including banking, finance, credit, assurance, excluding the labrir contracts.' 
services are accomplished in standard format for consumers and to powerless professionals and enterprises. ${ }^{16}$ The application of the Brazilian Consumer Code depends on the finding of a consumer. Article 2 of $\mathrm{CDC}$ provides a definition of a consumer sensu stricto: 'a consumer is any person or legal entity that purchases or uses a good or a service as a final addressee. 'But Article 29 of CDC expands rhese applications to all persons (professionals or not) exposed to a commercial unfair practice or clause. ${ }^{17}$ Here the jurisprudence seeks the concrete proof of the weakness of this consumer (consumidor equiparado).$^{18}$ Today all these relationships between banks and vulnerable customers ${ }^{19}$ should fall upon consumer protection provisions (Articles 2 and $29 \mathrm{CDC}$ ). ${ }^{20}$

The popular savings, credit to non-professionals, ${ }^{21}$ and small and vulnerable

${ }^{16}$ Leading cases: 'Contratos bancários. Relacão de consumo. A atividade bancária é conststutiva de relação de consumo e a ela é aplicável o Código de Defesa do Consumidor. Contrato de adesão. O contrato bancário caracteriza-se como de adesão porque suas cláusulas são impostas unilateralmente' (TJ/RSAPC 197055544,12 CC, j. 9 December 1997, Rel. Arno Werlang). 'Negociacão jurídica bancário - execucão contrato de bertura de crédito em conta corrente. Cheque especial empresa-juros - limitacão. A linitação dos juros procedida pela Câmara passa sempre pelo exame da situação fática. Surpreendida cláusula abusiva que disciplinava a cobrança de juros, sua anulação é decretada com base nas disposições do CDC aplicáveis à espécie, buscando-se na legislação infraconstitucional os parâmetros para a substituição da manifestação de vontade das partes' (TJ/RS- APC 198027765, 14" Câmara Cível, j. 15 April 1999, Nelson Antonio Monteiro Pacheco).

${ }^{17}$ New leading case: 'Negógio jurídico bancário. Contrato de abertura de crédito e financiamento de capital de giro 2) Revisaao de contratos renegociados, que continha cláusulas abusivas e, consequentemente, nulas de pleno direito. 3) Controle de cláusulas contratuais abusivas estipulacloras de encargos financeiros com base no Código de Defesa do Consumidor, inclusive em relação a pessoa jurídica (Article 29 do CDC)...(TJ/RS-APC 599050010, 1"Câmara de Férias Cível, i. 11 May 1999, Des. Paulo de Tarso Vieira Sanseverino). The first leading case was commented on in Marques, Contratos, n. 9 above, p. 158.

${ }^{18}$ Leading case: 'Contrato bancário. Embargos do devedor. Escriturapública de abertura decrádito pessoal banrisul....Incidência do código de defesa do consumidor. Aplicação do Código de Defesa do Consumidor a operações bancárias quando demonstrada sujeição do mutuário em face do mutuante, o que deve ser verificado no caso concreto' (T)/RS-APC 598557296, j. 11 February 1999, $18^{*}$ CC, Rel. Des. Jorge Luis Dall'Agnol).

${ }^{19}$ Leading case: Embargos infrigentes. Arrendamento mercantil. Acão de revisão de cláusulas contratuais. Aplicacão do codecon aos contratos de leasing. Abusividade na cobranca dos juros e encargos. Possibilidade de revisão. Embargos rejeitados' (TJ/RS-EI 598572303, $7^{\circ}$ Grupo Cível, j. 7 May 1999, Des. Henrique Osvaldo Poeta Roenick).

20 José Reinaldo de Lopes, 'Consumidor e Sistema Financeiro' (1997) Revista Direito do Consumidor, vol. 22 , p. 95. This author critized the jurisprudence position.

${ }^{21}$ Leading case: 'AVão de revisão contratual...contrato de abertura de crédito em conta corrente-pessaa fisica. Preliminar de carência de aVão não acolbida. Aplicação do CDC. Não repassados os custos a terceiros, o tomador de empréstimo é destinatário final, sendo uma relação de consumo típica' (TJ/RS-APC 198076994, j. 26 November $1998,18^{2}$ CC, Rel. Witson Carlos Rodycz). 
professionals, ${ }^{22}$ consumer credit ${ }^{23}$ and current accounts ${ }^{24}$ should be regulated by the Consumer Code.

\subsection{Prejudice Against Low Income Consumers and Technological} Advances

The very complex Brazilian experience with advances in electronic communication in banking can be interesting to compare with the Malaysian experience, not only hecause Sothi Rachagan does, ${ }^{25}$ but also because these two emergent economies have similar indicators in adult illiteracy, health and economic services in the 1990s and both countries have recently devalued their currencies and have very unique financial markets. Like Erik Jayme proposed, ${ }^{26}$ postmodern comparative law would be a comparison of the differences and not only a search for similarities. In these different legal responses to the problems of the consumers, there could be a sign to the cultural identity and to a specific market failure in this country. ${ }^{27}$

${ }^{22}$ Leading case: 'AVão de revisão contratual. Nota de crédito comercial 3. Código de Defesa ao Consumidor. Aplicável, na espécie. ...' (T]/RS-APC 198089732, 14² Câmara Civel, j. 8 April 1999, Marco Antonio Bandeira Scapini) and Revisão de contrato bancário. Embargos de devedor. Conexão. Julgamento simultâneo. Cédula de crédito comercial. Aplicabilidade do código de defesa do consumidor ... Apelação provida em parte' (TJ/RS - APC 197185986, $11^{2}$ Câmara Cível, j. 14 April 1999, Des. Voltaire de Lima Moracs).

${ }_{21}^{21}$ Leading case: 'Contratos com institui Vóes financeiras. Código do consumidor. Conforme expressiva doutrina, os contratos de crédito são abarcados pela tutela do código do Defesa do Consumidor ... Rejeitaram os embargos, por maioria' (EI 598604833, 4 Grupo de Câmaras Cíveis, j. 14 May 1999, Des. Luiz Felipe Brasil Santos\}.

${ }^{24}$ Arnaldo Rizzardo, Contratos de crédito bancário, 2. ed., RT, (São Paulo, 1994), P. 15.

${ }^{25}$ Socioeconomic comparative schema between Malaysia, Brazil and Canada, in Sothi Rachagan, 'Consumer Protection in the Rapidly Developing Economies of South Rast Asia: A Case Study from Malaysia' in Iain Ramsay (ed.) Consumer Law in the Global Economy, (Ashgate-Darmouth, Aldershot, England, 1997), Pp. 117 - 118. 26 Erik Jayme, "Visōes para uma teoria pós-modema do Direito Comparado" (janeiro 1999) in Revista dos Tribunais $759, \mathrm{pp} .24-40$.

${ }^{27}$ 'Selon le professeur allemand de l'Université de Heidelberg, M. Exik Jayme, le droit comparé postmodeme sera catactérisé par Yidenúfication du diffèrent dans les systèmes juridiques (das Trennende, die Unterschiede), par l'dentification du passager et momentanée (dem Flüchtigen, Zeitgenössische) comme significative d'un système juridique. L'idée ptincipale de Jayme est que à la phase moderne, dans la quelle le droit comparé servait comme auto-contrôle et re-afimation que toutes les juristes avaient - plus au moins - les mêmes pensées, et si les instruments étaient différents, les différences ne serait significacives (praesumtio similitudinis), si les résultats juste obtenues, alors, que ce phase là - de quasi simplification de la comparaison légal pour hipervaloriser le semblable et renforcer la loi nationale qui utilisait ces standards et modèles juridiques universelles - serait finie ou par finir. Les tendances contraires et les antinomies postmodernes stimulent la recherche pour une identité culturelle et nationale propre. La globalisation de l'économie rendre la comparaison des similitudes une évidence, un résultat bien entendu de pouvoir économique et de la circulation des modèles jutidiques. La finalité spéciale du droit comparé actuel devait être identifier les différences et les modes caractéristiques d'arriver au résultat juste, à une adaptation raisonnable à la réalité du pays, aussi bien les modes de respecter les droites individuels et droits humaines de chaque système juridique.' (Cláudia Marques, Rélations bancaires dans la societè d' information: une vision brèsilienne, forthconing. 
In Malaysia and other tapidly developing economies of South East Asia, as Rachagan has argued, consumer protection has not achieved its goals in the $1990 \mathrm{~s},{ }^{28}$ but the banking services are accessihle to almost all of the populations. ${ }^{29}$ In Brazil, the inverse situation has been achieved: consumer protection is in almost all economic sectors a reality, ${ }^{3 \theta}$ but the banking sector is not accessible to any consumer and it has been one of the most difficult areas for effectiveness in consumer protection. ${ }^{31}$

Three phenomena in the Brazilian banking market will now be discussed: an existence of a discrete prejudice against poor consumers through banking prices, ${ }^{32}$ an inefficient legal response in consumer over-indebtedness ${ }^{33}$ and a state seizure as a governance problem. ${ }^{34}$ In this essay I can only analyze tbe first one. Indeed, the Brazilian consumer protection law should have a distributive impact ${ }^{35}$ and achieve better conditions in consumer access to credit and hanking services in general. On this point, however, the protecrive measures have failed. The banking market tends to

${ }^{28}$ Sothi Rachagan, 'Consumer Protection in the Rapidly Developing ficonomies of South-East Asia: A case Study from alaysia' in Iain Ramsay (ed.), Consumer Law in the Global Economy, (Ashgate-Dartmouth, Aldershot, England, 1997), pp. $97-124$.

${ }^{2}$ Sochi Rachagan, 'Procedures for the resolution of consumer grievances with banking services' in Revista da AJURIS-Edição Especial 1998, tomo 1, (Porto Alegre, 1998), p. 203: 'Much of the law of banking developed during the nineteenth century and ignores two important subsequent developments. First, the nature of bank customers has changed, hen the law was being developed, bankers catered only for a small minority of the population; indeed the possession of a bank account was presurned to be the hallmark of financial respectability and wealth. This is no longer the case. Today virtually all adults and even minors hold bank accounts; many of who hold more than one account in the same or different banks. Second, the law was designed to cope with a few functions in a paper-based system and it cannot, without amendment, be extended to cover a variety of new functions, many reliant on computerized banking technology'.

${ }^{30}$ Antonio Herman Benjamin, El Código Brasileño de protección del consumidor, in Política y Derecho del Consumo, (E) Navegante Editores, Bogota, Colombia, 1998), p.479.

${ }^{31}$ Cf. Antonio Carlos Efing, 'Sistema Enanceiro e o Código do Consumidor' (1996) Revista Direito do Consumidor 17 , pp. $65-84$.

${ }^{32}$ This analysis will be based on the cases in Thomas Wilhelmsson 'Consumer Law and Social Justice', Iain Ramsay and Toni Williams, 'Inequality, Market discrimination and Credit Markets', and Geraint Howells, 'Seeking Social Justice for Poor Consumers' in Iain Ramsay (ed.), Consumer Law in the Global Economy, (Ashgate-Dartmouth, Aldershot, England, 1997), pp. 217 - 232, 233 - 256, 257 - 284.

${ }^{33}$ Cf. José Reinaldo de Lima Lopes, 'Crédito ao consumo e superendividamento- Uma problemática geral' (1996) Revista de Informação Legislativa 129 (Brazil), p. $109-115$.

${ }^{34}$ About the shrinking governance capacity of the state in Brazil, Leila Frischtak, 'State Capture and Fiscal Adjustment in Brazil', The World Bank ed., Private Sector Development Department, NR. 22, (1995), p. 29.

35. So Wilhelmsson, n. 32 above, p. 220: "The protection of debtors has been regarded as a mechanism for changing the division of benefts between the debtor and creditor classes. It has been seen as an important goal of credit and debt law to "redistribute power and resources generally from creditors to consumers". 
reproduce basic social injustices, so those consumers on low incomes are excluded from the bank sector, increasing their social integration problems. ${ }^{36}$

In an emergent economy with great credit and saving difficulties like the Brazilian one, these developments inctease the differences between the gtoups in society and create structural problems by distinguishing between: 1) the bomo economicus, an individual from the class $\mathrm{A}$ or $\mathrm{B}$ with credit, savings and a cutrent account in any national or international bank, who pays the bills automatically or tbrough Homebanking; 2) the bomo semi-economicus, an individual from the lower middle class with a current account to pay bills, but without credit or savings; and 3) the excluded bomo, an individual with low income who has no bank account; in the Brazilian financial market they must discount checks and withdraw pensions and unemployment benefits in a public bank. In addition, they must pay their bills and taxes in a public national bank and can purchase credit only with private facilitators (so called agiotas). ${ }^{37}$

In other wotds, their limited income also means that they have fewer opportunities to purchase financial services in the new banking market. The national public banks are almost all re-privatized in Brazil and seek a new profit policy, a senseless situation considering the credit problems of almost twothirds of the population. On the other hand, since the inflation and average annual rate is not so high, there is less money in the market and the bank transfer is the only mechanism to do such financial transfers. Almost all payments can be (or must be) done in banks and the poor consumers must pay higher taxes and stand in longer lines than other consumers with current bank accounts and savings. The new element in the picture is the technological advantages of the electronic era. The Brazilian banks have tapidly invested in adapting to this era, but the electronic technology produces new discriminations against the poor and the less educated. ${ }^{38}$ The effects of racial and gender prejudice in

\footnotetext{
${ }^{36}$ About these problems, see Geraint Howells, 'Seeking Social Justice for Poor Consumers' in Iain Ramsay (ed.), Consumer Law in the Global Economy (Ashgate-Dartmouth, Aldershot, England, 1997), p. 257.

${ }^{37}$ This is a such a common practice in Brazil that there is a special regulation about the 'fait' tax or interest in this lending form. $I_{t}$ is interesting to note that these rules fixing the 'fair' interest tax applies only to 'agiotas' and not to banks or any other official financial institution. See 'Class Action of Ministério Público from São Paulo and Leading Case' (1999) Revista Direito do Consumidor 29, pp. 192 and 178 .

${ }^{38}$ Luis Diez-Picaso, Derecho y masificación social/ Tecnologia y Derecho Privado (Dos exbozos), ed. Cuadernos Civitas, (Madrid, 1987), p. 95.
} 
banking are not common in Brazil $;^{39}$ only class discrimination is significant. The poor consumer may pay high banking taxes and have more difficulties to pay their bills. Payments for non-customers are allowed only in the 'Payments Central', far from downtown and with long lines and waiting time.

\subsection{Electronic Advantages in Banking Services}

In the $1990 \mathrm{~s}$, the mechanism of consumers'/customers' access to banking services began to cbange: (1) Automated teller machines were introduced in almost all Brazilian banks and a hankingnet called 'Banco 24 horas' was founded; (2) Banking cards and credit cards hecame accessible to more customers in Brazil; and (3) Home hanking by telephone and Internet also became available.

\subsubsection{Automated Teller Machines, Prices and Brazilian Consumers}

In the past all cashiers were persons and a popular commercial bank offered a great number of cashier's offices to theit customers. With the automatization and the evolution of the electronic cashier system, the Brazilian banks today offer a great number of automated teller machines (ATM) and a reduced numher of normal cashiers.

This 'evolution' has brought consequences: (1) Reorganization of agencies with more space for machines and little space and employees for cashiers; (2) Special cashiers were opened for disabled and elderly customers (rhose below 60 years of age), however, the banks have not considered the high rate of adult illiteracy in Brazil; (3) The creation of new jobs was necessary to help the normal Brazilian consumer to deal with these machines (not always in functioning order): the ATM assistant, i.e. a low-paid new employee working all day at from four to six ATMs in order to help in such automated operations; (4) An ATM bankingnet was founded and, in this 24-hour bank (Banco 24 boras), all services can be provided no matter what institution the consumer is a customer of; and (5) the waiting time in the lines doubled, as many cities tried to regulate the maximum waiting time (from 30 minutes up to 45 minutes in line!). The Brazilian Bank Federation has successfully contested this kind of local legislation, but rhe legal response was an interesting sign of how tbis technological change in banking has affected the life of the consumer.

\footnotetext{
${ }^{39}$ Some authors have considered the publicity about the racial and class discrimination of electronic technology unfair, but not the publicity of bank services; cf. Melina Penteado Trentin, 'A publicidade abusiva e o racismo' (1994) Revista Direito do Consumidor 11, p.67.
} 
These technological advantages in banking have changed the accounting and payment system in Brazil. Until recently the banks in Brazil have not tried to discourage the consumer from using the normal cashier by charging different roles. In Europe this is a normal procedure, but in an emergent country like Brazil this would create a great social injustice. The poor and less educated consumer, as well as elderly and disabled customers, ought to have the possibility of conducting banking services with a person teller and paying the same price as those who opted for using an automated teller. ${ }^{40}$ A price difference between the use of ATM and person tellers will have strong discrimination effects in Brazil and probably will be eventually forbidden (ex vi termini Article 5 Brazilian Constitution/1988). In Eutope, the superior courts have developed a so-called free access to account doctrine, where the banks are forbidden to charge consumers a monthly fee of 5 or 8 through personal cashiers, so the elderly, disabled and poor consumer can avoid the higher prices of the banking services and access their deposited money. To enable consumers make payments and have access to their accounts, a similar 'tight to access the deposit' through human cashiets free of charge is protected in Brazil.

2.2.2 Homes Banking, Interner Banking, Credit Cards and Other Banking Cards

To enable consumers to make payments, banks transfer money through four main forms: customer access to cash and cash distribution; checks and credit transfers, direct debits; and credit cards.

Home banking is a reality in Brazil, but only a few major banks give the consumers the chance to make withdrawals, payments, transactions, investments and to have account information on-line. No Brazilian banks give the consumer the chance to apply for credit on-line or via the Internet. In the most popular. Brazilian banks, the home-banking service is available only by telepbone. It is interesting to note that this service is normally conducted with the help of a bank employee. There is not yet, however, an electronic service with answering machines as in Europe, where the information is stored or recorded by means of a computer.

Home banking and Internet banking are just beginning in Brazil. Electronic communication offers real possibilities for improvement in the banking sector, but special safeguards must be adopted for the consumer credit context. It is interesting to note that for all contractual negotiations undertaken via the Internet

\footnotetext{
43 At the moment both kinds of access to service have the same price, or using a non-automated cashier is free of charge.
} 
(or telephone) Article 49 of the Brazilian Consumer Code provides a cooling-off period of seven days to cancel the contract without a motivation 'causa'. ${ }^{41}$ In credit and banking relationships in Brazil there is no possibihty for this cooling-off period or for cancelling these contracts. ${ }^{42}$

Credit-card schemes became very popular in Brazil in the late 1990s. Initially, the credit card providers used to send - without previous manifestation of the consumer - credit-cards to the homes of the consumers. Later a bill with the annual rate was sent to the consumer, and in many cases the annual rate judicial request was sent as a claim against the consumer. That practice was considered unfait or abusive ${ }^{43}$ and the credit-card providers (as well as the associated banks) were forced to pay the consumer's moral and material damages. ${ }^{44}$ The Department of Consumer Policy at the Ministry of Justice adjusted a collecrive conduct agreement with all credit-card providers in Brazil to ban this practice. All goods and services sent without previous manifestation of the consumer must be considered as a gratuitous promise (Article 39, III, $\mathbb{J}$ único of CDC). ${ }^{45}$

Because payment with credit-cards is not considered a 'cash' payment and the special promotional offers can normally he paid only by checks or cash, ${ }^{46}$ the creditcard schemes in Brazil do not break the nexus between the retailers and the credit provider. Normally the retailers do business directly with the credir provider and banks in order to sell in rates their products in Brazil. Many retailers offer credit products in their own store. In this scheme the credit is provided by a third parr. Article 52 of the Consumer Code provides a hink hetween this accessory credit and the main consumer contract, because it is uncertain if the consumer understands that they are contracting with a third party credit provider and if they are making an informed credit purchase decision when buying the goods.

\footnotetext{
${ }^{41}$ Cesar Matos Santolim, Formação e Eficácia Probatória dos contratos por computador, ed. (Saraiva, 1995), p. 39.

${ }^{42}$ For a suggested introduction of such cooling-off periods in consumer credit contracts, see Cláudia Matcues, 'Os contratos de crédito e a legislação brasileira de proteção do consumidor' (1996) Revista Direito do Consumidor 18, p. 53.

${ }^{43}$ Leading case: Tribunal de Justiça do Rio de Janeiro (1998) Revista Direito do Consumidor 27, p. 138.

${ }^{44}$ The problem was solved in a stnall claim court, so: 'Remessa de cartão de crédito a consumidor, sem solicitação prévia, constitui ilícito, conduta defesa pelo Código de Defesa do Consumidor. Se o Banco, sem assinatura no pacto ctediticio, leva à cobrança, e anota perante o Serasa o nome do pseudo cliente, pelo não pagamento das parcelas relativas à anuidade, e deş̧e fato advém danos de ordem moral ao cliente näo aderente, cabe ao banco o ressaxcimento.' ( $A$ c. 2'TR JEC/RS, Ap. 01597542776, , .11 November 1997), in Revista Direito do Consumidor 25 (1998), p. 157.

${ }^{45} \mathrm{Cf} .<w w w, m j . g o v /$ dpdc.br>.

${ }^{46}$ About this problem, see Ronaldo Porto Macedo Jr., 'Parecer: Cartöes de Crédito-Venda à vista' (1994) Revista Direito do Consumidor 9, pp. 197-203.
} 


\section{CONTRACTUAL RELATIONSHIPS BETWEEN BANKS AND CONSUMERS TODAY: CONSUMER PROTECTION IN FINANCLAL SERVICES IN BRAZIL}

The problems raised by standard bank contracts do not relate only to consumer protection, nor are abusive clauses and unfair banking practices the exclusive province of consumer contracts, ${ }^{47}$ but here $\mathrm{I}$ will focus only on the contractual relationship between banks and consumers. Everybody agrees that the consumer needs special protection for these contracts. The Brazilian Consumer Code provides special contractual duties during the contract negotiation and, after payment (Section 3.1), also provides a detailed reading of these contracts and develops rigotous unfair term's control (Section 3.2).

3.1 Special Contractual Banks' Duties: Consumers' Rights During the Negotiation and After Payment

\subsubsection{Information Duties: a Protected Choice of Financial Service}

The consumer has the right to a free choice and free purcbase of financial services. To enable this right the Consumer Code assures an information right (Article 6, III CDC). The Brazilian law imposed an information duty on the Banks (Articles 30, 35, 46, 52 and 54 CDC): i.e., a duty to inform the consumer about the goods or services, about the price and also about the contract terms. The Consumer Code provides two specific remedies connected wirh these information duties. On the collective dimension the government administration can control the delivery of this information and can impose different kinds of punishment like fines and prohibitions (Articles. 55, 56, 57, 58 and $59 \mathrm{CDC}$ ). The Public Attorney (Ministério Público) and the consumer organizations are allowed to control the information practices of the banks through class actions (Articles 81, 84 and $91 \mathrm{CDC}$ ). For the individual consumer, the failure of providing information can be safeguarded mainly through contractual remedies in connection with breach of contract (vicio de informação, Articles 20, 35 and 46 CDC).

The home banking, by telephone and Internet, raises a number of issues in connection with information that the consumer needs for the conclusion of a fair contract or a fair accessory transaction. The present Brazilian legislation is not considering these special needs, so there are not rules imposed or storage of the consumets' complaints. Articles 30,31, 46, 49,52 and 53 of the Consumer Code aim to provide quality information about particular services, the prices

${ }^{47}$ CE. Monteiro (1995) European Review of Private Law 3, p. 233. 
and the contract terms, ${ }^{48}$ but these information duties ate easy violated, having no rigorous control or sanctions against the hanks. The disclosure ${ }^{49}$ of Banking prices used to be a problem in Brazil.

The Consumer Code and the doctrine of good faith impose a new transparency ${ }^{50}$ in home (and Internet) banking, specially in questions about the price, time of delivery or completion of the service, contract clauses and mandatory legal rules, such as the Central Bank rules and the Consumer Code. As already mentioned, Article 49 of the Brazilian Consumer Code provides a cooling-off period of seven days to cancel all contracts negotiated by telephone. But because in home banking the consumer has already a current account contract with the bank, this cooling-off period may not apply. ${ }^{51}$ This cooling-off rule can not be used in normal credit and bank contracts, because they are not distance contracts; it will also be a very limited power in Internet and home banking. Here studies carried out by consumer organizations (and governmental institutions) demonstrate the lack of transparency in banking services in general. ${ }^{52}$ In Internet banking this lack of transparency and the easy access $s^{53}$ can also raise new problems of consumer over-indebtedness in an emergent country like Brazil.

\subsection{Cooperation and Care Duties: a Protection of Dignity}

The Brazilian Consumer Code and the doctrine of good faith tequire cooperative and responsible actions from the banks. ${ }^{54}$ The bank must cooperate with the customer/consumer to protect consumers' expectations based on the contract itself or on publicity about the product. The contract partners shall cooperate and shall not stand in the way of the realization of each contractual expectation (expectativas legitimas). Also, they must care about each other's dignity, honor and reputation. The violation of these duties by the banks may

${ }^{48}$ Cf. Marques, Contratos, n. 9. above, p. 324 and Santolim, n. 41 above, p. $38-39$.

49 About the consumer credit protection act in USA, see in David Epstein and Steve Nickles, Consumer Law (2nd edn, West Publishing, St.Paul, Minn., 1981), p. 97 and P. 114.

5Maxques, Contratos, n. 9 above, p. 106 and Agathe Da Silva, 'Cláusula geral de boa-fé nos contratos de consumo' (1996) Revista Direito do Consumidor 17, p.152.

5t Also Santolim, n. 41 above, p. 39.

${ }^{52} \mathrm{Cf}$. Study about Banking cost 'IDEC/PROCON-SP', <www.uol.com.br/idec>.

53 About mouse-click contracts, see Manoel J. Pereira dos Santos and Mariza Delapieve Rossi, 'Aspectos Legais do Comércio Eletrônico - Contratos de Adesão' (1999) Revista ABPI 43, foorthcoming.

${ }^{54}$ About 'good-faith' duties in Internet Contracts, see Santolim, n, 41 above, pp.36 - 37. 
cause extensive damages to the consumer and thus raises the possibility of contractual and non-contractual liability. ${ }^{55}$

A very common violation in Brazil is the inclusion of the consumer's name in the so-called Central Bank Services Databank (SERASA). The Brazilian Central Bank has also a databank named CADIN. ${ }^{56}$ The purchase of credit products and banking setvices in Brazil created a new danger to the consumer, i.e. that their names may be wrongly inctuded in a database either out of error or during a judicial dispute against the credit provider. ${ }^{57}$ In both databanks, the inclusion of the consumer's name when they have disputes in court against the banks are considered by the courrs as moral damage, ${ }^{58}$ violating the consumer code (Article $42 \mathrm{CDC}$..$^{59}$ The consumer can receive damages in accordance with the Consumer Code (Article 6, VI CDC).

The hank liahility in case of information losses or loss of orders and Internet protocols are considered an ordinary contractual (main) liability (Articles 18 and 20 CDC).

\subsection{Banks, Contractual Liability: Consumer Rights During the Contract}

\subsubsection{Interpretation of Consumer Contracts and Adequate Performance}

Article 37 of the Consumer Code provides a positive interpretation of consumers interests in all clauses in consumer contracts. Not only ambiguous

\footnotetext{
${ }^{55}$ Marques, Contratos, ת. 9 above, p. 326.

${ }^{56}$ Cf. Bertram Antônio Stürmer, 'Bancos de Dados e Habeas Data no Código do Consumidor' (1992) Revista Direito do Consumidor 1, pp. $55-94$.

${ }^{57}$ Leading cases of the Superior Tribunal de Justiça: SPC, Serasa, Cadin. Exclusão do registro. Liminar. Pendência de ação ordinária. Não cabe a inclusão do nome do devedor em bancos particulares de dados (SPC, Cadin, Serasa) enquanto é discutido em ação ordinária o valor do débito, pois pode ficar descaracterizada a inadimplência, causa daquele registro'(Resp. 188390-SC, j. 22 March 1999). 'Deve ser cancelada a inscrição do nome do devedor em banco de inadimplentes se o contrato está sendo objeto de ação revisional, em que se discute a validade de cláusulas, valor do saldo e a própria existência da mora' (Resp. 205039-RS, j. 6 May 1999 forthcoming).

${ }^{58}$ Leading case: $1^{\circ}$ Tribunal de Alçada Cível São Paulo: 'Hipótese de remessa injusta de nome de mutuário aos sistemas de proteçăo de crédito. Nào caracterização de inadimplência dada a litigtosidade da matéria. llicitude da remessa. Constrangimentos havidos quando à movimentação de cheques. Aplicação da teoria do valor de desestínulo. Majoração do quantum' in (1998) Revista Direito do Consumidor 28, p. 165.

${ }^{59}$ Cf. 'Class Action of Ministério Público São Paulo' (1997) Direito do Consumidor 22, pp. $322-332$ and decision Pp. $275-282$.
} 
clauses merit a positive interpretation, but all contract terms (written or unwritten, but from the publicity or simple promises of the seller and employees of a company, Articles 30, 34, $48 \mathrm{CDC}$ ) should be interpreted according to consumer interests. ${ }^{60}$

Article 20 of the Consumer Code provides an outline of adequate service performance, but certain equipment failures (hardware), malfunctions (software) and involuntary human errors (ertor by processing data) may happen. In fact, both hardware- and software-driven ATM (Automatic Teller Machines) and home banking networks are products that have been tested at a great number of installations, where millions of transactions take place. Here there is a professional bank risk if this software and hardware can not perform adequately. ${ }^{61}$ In Brazil there are more common errors related to user identification (unauthorized users), use of fraudulently obtained identification codes, failures in the securiry of home banking systems and in the ' 24 hour bank system'. Delays in message transmission are considered normal $(24 \mathrm{~h}-48 \mathrm{~h}$ are the normal bank delays in Brazil). ${ }^{62}$ The Brazilian banks must have an uninterrupted power supply, but the supply of energy is not always continuous, so the disappearance of information is not impossible; thus the banks must have copies and other permanent matetials (i.e. wriring orders, protocols, etc.) to deal with these problems. In home banking hy Internet and by phone there is a lack of reliability (but not substantially greater than in the normal hanking services). The Brazilian bank system shows a good efficiency even though in a third world country, but with high costs and lack of fairness (unauthorized double charging, new tax on interest, unfair commercial practices, etc.) in its contacts with consumers.

In Brazil payment or funds transfer with cyber coins are not yet used. In my opinion, the adequate performance of home banking services must include the right to have a copy of the bank contract or transaction in a 'permanent' way. ${ }^{6.3}$

\footnotetext{
6o Marques, Contratos, n. 9 above, pp. 105 - 115.

6) Santolim, n. 41 above, p. 23.

${ }^{62} \mathrm{Ibid}$.

${ }^{63}$ Also in Europe, cf. J. Oliveira Ascensäo, 'Diteitos do Utilizados de Bens Informáticos' in Antónjo Monteiro (ed.), Comunicação e Defesa do Consumidor (Faculdade de Coimbra, Coimbra, 1996), p. 351. And Peter Mankowski, 'Internet in Internationalen Vertrags- und Deliktsrecht' (1999) RabelZ 63, pp. 203 - 294. In Brazil, Santolim, n. 41 above, p.36.
} 
3.2.2 Ptotection Against Unfair Contract Term and Practices in Financial Services

The doctrines of good faith (Princípio da Boa-fé objetiva) and on laesio enormis (lesão enorme) ${ }^{65}$, both accepted by the Brazilian Consumer Code (Article 4, III c/c and Article $6, V I, V C D C$ ), give the Brazilian courts the power to control, excuse ot modify terms in contracts between consumers and banks. ${ }^{66}$ Such judicial modification of contracts (specially the modification on the tax on interest) or judicial interfetence in the basic principle of freedom of contract (i.e., nullification on unfairness clauses) has been subjected to strong criticism on economic grounds, but is justified on the ground that it protects the weak or ignorant from exploitation. Banks and consumers have unequal bargaining and lobbying powers, so the Consumer Code tries to bring some contractual justice and equality of chances.

The most used Consumer Code doctrine is that of good faith (Articles 4, III, $6, \mathrm{VI}$ and $51 \mathrm{CDC}$ ). This doctrine is understood as serving two different goals: to create obligations of proper conduct (função criadora ou positiva, in German pflichtenbegrundende Funktion) and to impose limits on conduct and prevent unfairness (função limitadora, in German Scbranken-bzw. Kontrollfunktion). ${ }^{67}$ Usually coutts invoke the doctrine to protect consumers' expectations based on the contract itself or on publicity ( $\Lambda$ rticles $30,34,46$ and $48 \mathrm{CDC}$ ), but courts use the doctrine to prevent the strong party (i.e., the bank, credit-card corporation or leasing corporation) from selfishly injuring the weak party (i.e., the individual consumet and small enterprises) in financial contracts (Articles 51,52,53 and $54 \mathrm{CDC}$ ). The Brazilian Consumer Code considers unfair contract terms null (Article $51 \mathrm{CDC}$ ) and provides controls for individual negotiated and standatd conrracts (Articles. 51 and 54. CDC). ${ }^{68}$

\footnotetext{
64 Marques, Contratos, n. 9 above, pp. $105-115$.

${ }^{65}$ Cr. Cáio Mário da Silva Pereira, Lesão nos Contratos, (3rd edn, Forense, Rio de Janeiro, 1993), p.1.

${ }^{65}$ Ruy Rosado de Aguiar Jr., 'A boan-fé na relação de consumo' in Revista Direito do Consumidor vol. 14, p. 20 .

${ }_{67}$ Clóvis Couto e Silva, 'O Princípio da Boa-Fé no Direito Brasileiro e Português' in O Direito Privado brasileiro na visáo de Clóvis do Couto e Silva (Livraria do Advogado, Porto Alegre, 1997), p. 38. Also for the advice of the Brazilian and the Portugese Authors, see Marques, Contratos, n. 9 above, p. 108 and Antonio Menezes de Cordeiro, Manual de Direito Bancário (Almedina, Coimbra, 1998), p. 304 and Antonio Pinto Monteiro, 'The Impact of the Directive on Unfair Terms in Consumer Contracts on Portuguese Law' (1995) European in Review of Private Law 3, pp. 231 - 240.

${ }^{68}$ Leading case: Superior Tribunal de Justiça, in (1998) Revista Direito do Consumidor 27, p. 118.
} 
These doctrines have enabled the Public Attorney to control all consumers' standard hank contracts (Article 51, $\ 4^{\circ} \mathrm{CDC}$ ) ${ }^{69}$ Even examples of the judicial bank contracts control can be given: the bank interest and taxes were controlled and the use of some 'bis in idem' indexes ${ }^{7 / 3}$ was forbidden. The mandate clause in favour of the bank or any enterprise of the same group is considered null. ${ }^{71}$ The election's clause of the forum in the interest of the bank is also considered null. ${ }^{72}$ An old credit provider's benefit was overruled in car leasing: thus there are no longer debtor's prisons in Brazil. ${ }^{73}$

Today almost 60 per cent of the civil claims deal with banking services and the control of unfair terms and practices, which shows how big the importance of this marter is in Brazilian society. In the last ten years, the financial services market in Brazil has changed and introduced a substantial growth in credit card, and electronic banking card, telephone and Internet home banking schemes. The Brazilian Consumet Code is the only protective legislation for consumers in this very complex banking field. The increasing deregulation of financial services, the privatization and re-grouping (fusion) tendencies demand the adoption of more rigorous legal and control measures, including more specific rules about consumer protection in electronic financial services. $^{74}$

69 'Class Action of Ministério Público do Rio Grande do Sul (1994)' in Direito do Consumidor 17 (1996), p. 354 .

${ }^{70}$ Leading cases about the 'TR', 'INPC', in (1999) Revista Direito do Consumidor 29, pp. 148 and 163. Against the use of the 'Price Table' in consumer credit, Márcio Mello Casado, 'O uso da tabela price no crédito ao consum' (1999) Revista Direito do Consumidor 29, p. 72.

7 'Class Action of Ministério Público Rio Grande do Sul' in (1996) Direito do Consumidor 18, p. 275. Tribunal de Justiça Minas Gerais (1996) Revista Direito do Consumidor 20, p. 163. Leading case of the Superior Tribunal de Justiça: Súmula 60 do STJ: 'É nula a obrigação cambial assumida por procurador do mutuário vinculado ao mutuante, por exclusivo interesse deste.' Also Alberto do Amaral Jx., 'A abusividade da eláusula mandato nos contratos financeiros, bancários e de cartões de crédito' (1996) Direito do Consumidor 19 , pp. $148-160$.

${ }^{72}$ Cf. $1^{10}$ Tribunal de Alçada de São Paulo (1996) Revista Direito do Consumidor 20, p. 158, "Tribunal de Justiça Minas Gerais' (1996) Revista Direito do Consumidor 20, p. 160.

${ }^{73} \mathrm{Cf}$. Habeas Corpus in (1995) Direito do Consumidor 15, p. 204. New leading case of the Superior 'Tribunal de Justiça, Habeas Corpus n. 5583-DF (forthcoming).

${ }^{74}$ Cf. Antonio Herman Benjamin, 'Tnternet and E-conmerce' in IV Congresso Argentino de Derecho Civil, (Santa Fé, September,1999, forthcoming). 